Гордійчук Катерина

здобувач вищого освітнього ступеня «Магістр», спеціальності «Психологія»

Рівненського державного гуманітарного університету

ORCID iD: 0000-0002-3760-7987

DOI https://doi.org/10.35619/prap_rv.vi13.116

\title{
ПСИХОЛОГІЧНІ ОСОБЛИВОСТІ ПРОФЕСІЙНОГО САМОВИЗНАЧЕННЯ СТАРШОКЛАСНИКІВ
}

Анотація. У статті розкрито сутність професійного самовизначення особистості, розкривається зміст критеріїв та показників ї̈ сформованості в ранній юності. Виокремлено основні положення науковиів щзоо феномену особистісного самовизначення, здійснено узагальнення щзодо самооиінки у ранній юності. Актуалізується проблема становлення професіонала, проблема особистісного $i$ сочіального розвитку майбутнього спеціаліста як суб'єкта соціальної дії та основні фактори впливу на вибір професії.

У статті наводиться опис особливостей професійного самовизначення учнів юнацького віку, з'ясована роль інтересів та здібностей у професійному самовизначенні школярів, вказано особистісні характеристики, які сприяють успіху молодої людини в професійній діяльності.

Ключові слова: професійне самовизначення, самоочінка, рання юність,когнітивна складність професійних домагань.

Постановка проблеми. Професійне самовизначення в широкому розумінні - це процес, який охоплює весь період професійної діяльності особистості: від виникнення професійних намірів до виходу з трудової діяльності, тобто реалізується упродовж життя людини. Центральним моментом цього процесу є вибір професії, що стає переломним етапом в житті людини та визначає подальший розвиток життєвого шляху, i, зазвичай, співпадає із закінченням школи. Вибір професії - складний і відповідальний крок у житті людини. Зробити правильний вибір - значить знайти своє місце в житті. Неправильний вибір професії завдає великої шкоди самій людині та призводить до значних економічних втрат, пов'язаних 3 використанням трудових ресурсів. Вибір професії визначає і матеріальний добробут, $\mathrm{i}$ ступінь свободи творчості. Від успішності кар'єри залежить рівень задоволеністю життям у цілому.

В жорсткі умови праці потрапляє сучасна молодь, яка прагне здобути хорошу професію відразу після закінчення навчання, мріє про швидкі професійні досягнення, матеріалізовані в зовнішніх атрибутах успішної людини, й при цьому не бажає повною мірою працювати над собою, підвищувати свій особистісний і професійний рівень,розвивати необхідні для обраної професії професійно важливі якості. Такі протиріччя й визначають актуальність проблеми дослідження професійних особливостей розвитку самооцінки й професійних домагань сучасних учнів старшої школи як динамічних підсистем процесу професійного самовизначення особистості.

Аналіз останніх досліджень 3 проблеми. Слід сказати, що питання професійного і особового самовизначення є об'єктом пильного вивчення як вітчизняних, так і зарубіжних психологів. У своєму дослідженні ми спиралися на концепції професійного самовизначення і вікових особливостей розвитку особистості в ранній юності (Дубровіна, Кон, Слободчиков, Ісаєв, та ін.). Проведений нами аналіз праць вчених близького зарубіжжя (Гриншпун, Йовайша, Карпов, Маркова, Платонов, Чистякова та ін.). Свідчить про те, що в останнє десятиліття проблеми професійного самовизначення особистості розглядаються у контексті значно ширшого поняття «професійний розвиток особистості» і пов'язане це, передусім, 3 
необхідністю виокремлення найбільш сенситивних періодів формування іiі складових. (Вікова та педагогічна психологія, 2004, с. 401).

Таке розуміння цього процесу дає змогу не лише сформувати в особистості готовність до вирішення певних задач, пов'язаних з ії професійною діяльністю, наприклад, вибору майбутньої професії. Найважливішим результатом за такого підходу стає вироблення в особистості ставлення до себе як суб'єкта майбутньої професійної діяльності, яке забезпечить у разі потреби зміну професії або ж сфери трудової діяльності. Проблема визначення критеріїв і показників сформованості професійного самовизначення особистості якраз i перебуває в межах цих досліджень, в якій вона розглядається вченими як обов'язковий i надзвичайно важливий етап професійного саморозвитку особистості та головний механізм формування її як суб'єкта праці.

Специфіка професійного самовизначення в ранній юності визначається, 3 одного боку,- динамікою і мінливістю світу професій, а, отже,необхідністю освоєння нового соціально-економічного досвіду, з іншою, - пошуком внутрішньої підвалини для реалізації цього процесу. Цією «внутрішньою підвалиною», «точкою відліку» в умовах відсутності певної професійної мотивації і невираженості спеціальних здібностей може стати комплекс темпераментно-зумовлених особливостей, як інтеграційна характеристика природних властивостей людини. Професійне самовизначення особистості тісно пов'язується 3 ii професійним розвитком і в працях Платонова. Відомий вчений у галузі професійного розвитку людини стверджує, що процес розвитку суб'єкта професійної праці тісно пов'язаний зі становленням іiі професійного самовизначення. Останнє ж є критерієм успішності початкового етапу професійного розвитку особистості (Платонов, 2011, с. 18).

В ранній юності головною проблемою, навколо якої зосереджені думки, мрії і сподівання дітей, ними визначено уточнення соціально професійного статусу й початок формування професійно важливих якостей в умовах поглибленого вивчення навчальних предметів, до яких виявилися стійкі інтереси (Журкина, Чистякова, 2009, с. 16). Переважна більшість вчених доходить до висновку про необхідність виділення етапів або ж стадій професійного самовизначення особистості, оскільки цей процес не зводиться лише до здійснення акту вибору певної професії, а триває впродовж всього життя людини. Адже узгодження особистісних і професійних потреб особистості охоплює весь період трудової діяльності людини, що свідчить про незавершеність професійного самовизначення особистості. Таке положення дозволяє нам виокремити специфічні особливості цього процесу в ранній юності й окреслити ті орієнтири, які мають бути сформовані в цьому періоді вікового розвитку дитини. Ми згодні з тим, що самовизначення - центральне питання раннього юнацького віку, але нам хотілося б ввести в цю проблему деяке уточнення. Дані наших досліджень дозволяють говорити, що в старшому шкільному віці формується не саме професійне самовизначення, а психологічна готовність до нього.

Психологічна готовність до самовизначення припускає формування у старшокласників деяких психологічних утворень і механізмів, що забезпечують їм надалі свідоме, активне і творче життя. У психологічній готовності до самовизначення,безумовно, провідну роль грає самосвідомість - усвідомлення своїх якостей і оцінка їх, уявлення про своє реальне і бажане Я. Рівень домагань старшокласників у різних сферах життя i діяльності, оцінка себе і іншого з точки зору приналежності до певної статі, інтроспективна i особистісна рефлексія; 3 усіх цих питань існують конкретні експериментальні дані i проведений їх змістовний аналіз. «Усвідомлення свого місця в майбутньому, своєї життєвої перспективи». Отже, як зазначають науковці, професійне самовизначення: 1) пов'язане 3 певною діяльністю людини; 2) для його реалізації у людини повинен бути сформований образ бажаного майбутнього; 3) людина повинна усвідомлювати свої можливості та обмеження; 4) враховувати потреби соціуму (Психологічні основи профорієнтації i професійного самовизначення, 2009, с. 22).

Мета статті. Виявлення факторів, умов та індивідуальних особливостей професійного самовизначення особистості. Визначення критеріїв і показників сформованості професійного самовизначення особистості в ранній юності. Професійне самовизначення в широкому 
розумінні - це процес, який охоплює весь період професійної діяльності особистості: від виникнення професійних намірів до виходу з трудової діяльності, тобто реалізується упродовж життя людини. Центральним моментом цього процесу є вибір професії, що стає переломним етапом в житті людини та визначає подальший розвиток життєвого шляху, $\mathrm{i}$, зазвичай, співпадає із закінченням школи.

Виклад основного матеріалу дослідження. У психолого-педагогічній літературі зазначається, що самовизначення - це складний, багатоступінчатий процес розвитку людини. Його структурними елементами $є$ різного роду самовизначення: особистісне, соціальне, професійне тощо. Ці види постійно взаємодіють, проте найчастіше вони відбуваються одночасно, зумовлюючи один одного. В свою чергу, Клімов (2003) зазначає, що професійне самовизначення - це образ бажаного майбутнього, особливості усвідомлення себе й свого місця в системі ділових міжособистісних стосунків. Вчений експериментально доводить, що самовизначення - це не одноразовий акт вибору, а низка рішень упродовж усього віку людини, які обумовлені способом його життя (с. 512).

На професійне самовизначення впливає багато чинників: активність самого суб'єкта самовизначення, соціальні та економічні чинники, культура, відповідальність людини за своє життя в цілому, особливості майбутньої професійної діяльності, особистісна зрілість та готовність до здійснення вибору, рефлексивні здібності, особливості самосвідомості, індивідуально-типологічні особливості суб'єкта професійного вибору. Рефлексія власного життєвого шляху, прагнення до самореалізації призводить до появи нових соціальних потреб: знайти своє місце серед інших, виділитися, бути особливим, грати певну роль в суспільстві. Виникає відповідальність не просто за себе, а за себе в спільній справі, за спільну справу і за інших людей. Традиційно виокремлюють суб'єктивні та об'єктивні чинники вибору професії. До суб'єктивних належать інтереси (пізнавальні та професійні, інтерес до професії, нахили), здібності (психологічні властивості, що необхідні для успішного виконання певного виду діяльності), темперамент, характер. Група таких об'єктивних чинників включає рівень підготовки (академічна успішність), стан здоров'я, проінформованість про світ професій. Однак вже в шкільному віці формуються певні уявлення про майбутню професію, які на наш погляд, зумовлюють такі важливі аспекти, як: досвід, обізнаність, емоційне ставлення та мотивація.

Отже, професійне самовизначення особистості це довготривалий і динамічний процес самостійного узгодження досягнутих, але ще нереалізованих нею можливостей і вимог обраної або ж бажаної професії. Результатом цього процесу в ранній юності є готовність старшокласника до професійного самовизначення, становлення якої супроводжується уточненням майбутнього соціально-професійного статусу та початком формування професійно важливих якостей,необхідних для успішної професійної діяльності в майбутньому. Новоутворенням цього віку є самовизначення старшокласників в людському суспільстві, усвідомлення своїх можливостей і прагнень, свого призначення в житті. Старшокласникам притаманна особлива схильність до активної діяльності, самостійності. Тому особливою умовою формування у юнаків здібностей до певної професії $\epsilon$ ознайомлення зі світом професій, засвоєння загально-трудових умінь і навичок. Проміжною ланкою між вимогами майбутньої професії та можливостями учня є його самодіяльність у напрямі зрівноважування, через сформоване ставлення до професії та до себе як суб'єкта праці, об'єктивних вимог професійного простору та суб'єктивних факторів оволодіння в майбутньому бажаною професією.

Можна відзначити, незважаючи на достатньо грунтовні дослідження цієї проблеми, на даний час до його змісту вчені відносять різні за значенням складові, а також виділяють неоднакові критерії та показники сформованості внутрішньо-особистісного утворення індивіда. I це закономірно, адже предметом таких досліджень виступають різні періоди розвитку особистості, впродовж яких вирішуються специфічні для кожного віку завдання. Тому визначення критеріїв і показників професійного самовизначення особистості в ранній юності й має грунтуватися на тих актуальних завданнях, соціальна ситуація розвитку яких дає змогу успішно подолати протиріччя між об’єктивними вимогами середовища розвитку та 
суб'єктивними факторами (самооцінка та професійні домагання) оволодіння в майбутньому бажаною професією. До вимог середовища розвитку належить об'єктивна потреба в обов'язковому вирішенні випускником загальноосвітнього навчального закладу питання майбутнього i професійного зокрема. Суб'єктивні фактори визначаються тим, що вирішується згадана проблема на основі уявлень особистості про майбутню професію, без реального досвіду діяльності в ній, без перевірки своїх можливостей у виконанні певних виробничих завдань, без інших і не менш значущих відомостей, які можна отримати лише в практиці трудової активності. Когнітивна складність системи знань старшокласника про себе, свої можливості та вимоги обраної або ж бажаної професії є другим критерієм сформованості професійного самовизначення особистості в ранній юності. Показниками цього критерію виступають знання дитини про власні індивідуальні особливості, знання про специфіку професійної праці людини та її вимоги й адекватна оцінка таких знань. Визначені нами критерії сформованості професійного самовизначення особистості є тими динамічними підсистемами цього процесу, розвиток яких спонукає розвиток останньої, який може здійснюватися в напрямі самовдосконалення до рівня вимог обраної професії, зниження рівня професійних домагань внаслідок завищеної самооцінки й вибору професії 3 нижчим рівнем вимог, відхід від вирішення проблеми або підвищення рівня домагань.

Висновки і перспективи подальших розвідок. Отже, професійне самовизначення - це складне особистісне утворення, яке проявляється у самореалізації особистості в професійній діяльності в результаті найбільш повного використання нею власних здібностей й індивідуально-психофізіологічних можливостей із врахуванням вікових особливостей розвитку, це пошук «своєї» професії, визначення для себе професійних перспектив та їх досягнення. Професія все більше починає розглядатися і як засіб для досягнення життєвого успіху, і як засіб для знаходження свого місця в суспільстві, і як засіб самореалізації особистості. Адекватне професійне самовизначення - це головне досягнення успіху в професійній діяльності. Образ майбутньої професії досить складне утворення, що включає емоційні і когнітивні компоненти. Для обгрунтованості професійного вибору необхідно також, щоб вимоги з боку професії відповідали можливостям людини. Результатом цього процесу в ранній юності $є$ готовність старшокласника до професійного самовизначення, яка $\epsilon$ особистісним новоутворенням, що формується у процесі цілеспрямованого впливу й забезпечує узгодження старшокласником знань про зміст і структуру світу професій та їх вимоги до людини зі сформованими та усвідомленими ним в процесі розвитку можливостями та потребами. В іншому випадку у самосвідомості людини накопичується негативний життєвий досвід, формуються своєрідні способи вирішення поставлених перед ним завдань - відхід від проблем, їх ігнорування. Критеріями сформованості професійного самовизначення особистості в ранній юності визначено: когнітивну складність та адекватну самооцінку системи знань старшокласника про себе та майбутню професію; диференційоване ставлення до власного професійного майбутнього та свого місця в середовищі професійної праці.

Тому, на нашу думку, актуальним є подальше емпіричне дослідження професійного самовизначення учнівської молоді в поєднанні із соціальним самовизначенням, вивчення ціннісних орієнтацій учнів, життєвих планів та професійних намірів. Подібне дослідження може стати одним із засобів поліпшення наукової організації профорієнтаційної роботи, підвищення iї ефективності, що сприятиме успішному професійному самовизначенню.

\section{СПИСОК ПОСИЛАНЬ}

Демидова, Т. (2001). Психологическое сопровождение профессионального самоопределения специалиста. Специалист, 3, 14-16.

Климов, С. (2003). Как выбирать профессию. Москва.

Леонтьев, А. (2007). Деятельность. Сознание. Личность. Москва.

Мельник, О. (2009). Професійна орієнтація старшокласників: теорія і практика. Київ.

Побірченко, Н., Литвинова, Н., Синівський, В., Мерзлякова, О. (2011). Технологї̈ професійної орієнтащіï населення в умовах ринку пращі. Київ: Педагогічна думка.

Випуск 13, 2019 Збірник наукових праць РДГУ. 
Титаренко, Т., Лебединська, І. (2007). Життєві домагання особистості. Київ: Педагогічна думка.

\section{REFERENCES}

Demydova, T. (2011). Psikhologicheskoye soprovozhdeniye professional'nogo samoopredeleniya spetsialista [Psychological support of the professional self-deter mination of the specialist]. Spetsialist, 3, 14-16. [in Russian].

Klimov, E. (2003). Kak vybirat' professiyu [How to choose a profession]. Moskva. [in Russian].

Leontev, A. (2007). Deyatel'nost'. Soznaniye. Lichnost' [Activity. Consciousness. Personality]. Moskva. [in Russian].

Melnyk, O. (2009). Profesiyna oriyentatsiya starshoklasnykiv: teoriya i praktyka [Professional orientation of high school students: theory and practice]. Kyiv. [in Ukrainian].

Pobirchenko, N., Lytvynova, N., Synivskyi, V., \& Merzliakova, O. (2011). Tekhnolohiyi profesiynoyi oriyentatsiyi naselennya $v$ umovakh rynku pratsi [Technologies of vocational orientation of the population in the conditions of the labor market]. Kyiv: Pedahohichna dumka. [in Ukrainian].

Tytarenko, T., \& Lebedynska, L. (2007). Zhyttyevi domahannya osobystosti [Life harassment of the individual]. Kyiv: Pedahohichna dumka. [in Ukrainian].

\section{PSYCHOLOGICAL FEATURES OF PROFESSIONAL SELF-DETERMINATION OFHIGH SCHOOLSTUDENTS}

Catherine Gordiychuk graduate student, specialty "Psychology" Rivne State University of the Humanities ORCID iD: 0000-0002-3760-7987.

DOI https://doi.org/10.35619/prap_rv.vi13.116

Abstract. The article reveals the essence of professional self-determination of personality and the content of criteria and markers of its maturity in early youth. The article defines the fundamental principles of the scientists about the self-determination phenomenon and makes generalization of self-esteem in early youth. The problem of becoming a professional, the problem of personal and social development of a future specialist as a subject of social action and the main factors influencing the choice of profession are actualized.

The article describes the features of professional self-determination of young students, clarifies the role of interests and abilities in the professional self-determination of students, shows personal characteristics that contribute to the success of young people in their professional activity, as well as shows the main differences that exist in high school students when living perspectives and strategies. Senior adolescence is the time to choose a person in his life path. Issues related to social, personal and professional self-determination become central at this age. Reflections on one's life prospects, experimenting with different social roles, finding answers to questions about the meaning of life occupies a leading place in the life of a graduate. The desire to act in accordance with their values, ideals and interests becomes urgent; willingness to take responsibility for your life. Professional self-determination is an extremely important stage in the life of every person, because a properly made professional choice determines the success of a person's professional activity and psychological comfort. The problem with the professional choice of upperclassmen is that they have to make responsible and independent choices about their future. Making this choice requires a purposeful process that aims to identify your future destination. Quite often, modern school graduates find themselves in a situation of professional self-determination without some motivation, without realizing the importance of this step, since there is a significant risk of a wrong choice that can lead to personal frustration and slow down the professionalization process.

Keywords: professional, self-determination, self-esteem, earlyyouth, cognitivecomplexity of professionalambitions. 